\title{
CIRCULATING LEVELS OF CELL ADHESION MOLECULES IN HYPERTENSION
}

\author{
Kavita K Shalia, Manoj R Mashru*, Jagdish B Vasvani*, Rajashree A Mokal, \\ Shilpa M Mithbawkar and Priti K Thakur
}

Sir H. N. Medical Research Society, Sir H. N. Hospital and Research Centre, Raja Rammohan Roy Road, Mumbai 400004 ${ }^{*}$ Sir H. N. Hospital and Research Centre, Raja Rammohan Roy Road, Mumbai 400004

\begin{abstract}
Hypertension causes complications such as coronary atherosclerosis and thrombosis wherein inflammatory factors play significant role. In the present study inflammatory molecules such as cell adhesion molecules (CAMs); endothelial (E)-selectin, platelet (P)-selectin, intercellular CAM-1 (ICAM-1), vascular CAM-1 (VCAM-1) and platelet endothelial CAM-1 (PECAM-1) were analysed in subjects newly diagnosed with hypertension with no secondary cause against normotensive healthy individuals. In each group 57 subjects were recruited and soluble (s) levels of CAMs were analysed by ELISA. As compared to controls median of sE-selectin (49.2\%, $P=0.001)$, s $P$-selectin $(54.3 \%, P=0.001)$, and sICAM-1 (18.9\%, $P=0.012)$ were significantly elevated in hypertensive subjects. Significant negative correlation was observed of sP-selectin (spearman rank correlation coefficient $(r s)=-0.345, p=0.027)$ and $s P E C A M-1(r s=-0.446, p=0.003)$ with age in hypertension group. Hypertension may increase expression of certain CAMs while younger hypertensives in addition are also at increased risk of atherothrombosis.
\end{abstract}

\section{KEY WORDS}

Hypertension, Cell adhesion molecules, Selectins, ICAM-1, VCAM-1, PECAM-1.

\section{INTRODUCTION}

Cardiovascular diseases (CVDs) have emerged as a global health problem. Essential hypertension (EH), increases pressure in arteries with no specific medical cause is one of the major risk factor for CVD. It synergistically with other risk factors such as diabetes mellitus (DM), hypercholesterolemia, smoking etc., increases the risk for CVDs especially in the elderly (1-3). The pathologic effects of increased blood pressure such as endothelial dysfunction and disturbed balance between vasoconstrictive and vasorelaxing factors result in changes in blood vessels including fibromuscular

\section{Address for Correspondence :}

\section{Dr. Kavita K. Shalia,}

Sir H. N. Medical Research Society,

Sir H. N. Hospital and Research Centre,

Raja Rammohan Roy Road,

Mumbai 400004.

E-mail:Kavita_shalia@hnhospital.com,

kavitashalia@hotmail.com hyperplasia of vessel walls and accelerated arteriosclerosis $(4,5)$ leading to coronary artery disease $(C A D)$, congestive heart failure, stroke and renal failure.

Currently, it is well known that inflammatory factors play significant role in the mechanisms that trigger and enhance remodeling of the vascular wall. These factors are released from damaged cells of the vascular wall and from cells infiltrating this wall, namely monocytes, lymphocytes, and granulocytes (6). Among inflammatory molecules cell adhesion molecules (CAMs) play important role in accelerating the process of atherosclerosis. They are selectins, endothelial $(E)$ - and platelet $(P)$ - which mediate leukocyte rolling on vascular endothelial wall and platelet-leukocyte interaction respectively. Firm attachment of cells to the vascular endothelial wall is carried out by intercellular cell adhesion molecule-1 (ICAM-1) and vascular cell adhesion molecule (VCAM-1) (7). Subsequent migration through endothelium requires expression of VCAM-1 and platelet endothelial cell adhesion molecule -1 (PECAM-1) (8). 
Increased blood pressure apart from various pathological changes (9) also increases production of free radicals by angiotensin II (10), latter being significantly correlated with inflammation (11). Incomplete oxidation and enhanced production of free radicals may be associated with medial thickening, which could prolong the diffusion of oxygen from the vascular lumen (12). This increased production of free radicals in endothelium may trigger a cascade activating the transcription factor nuclear factor kappa B (NFkB), which in turn regulates expression of molecules such as ICAM-1 (13). Thus expression of CAMs may be regulated at the transcription level (14) that may consequently influence serum concentration of soluble forms of CAMs. Experimental evidence came in when Buemi et al (15) demonstrated the relationship between increased blood pressure and increased levels of adhesion molecules in plasma. In their study, even a short-term increase in blood pressure, induced with cold pressor test (CPT) was accompanied by a significant increase in soluble (s) levels of ICAM-1.

Soluble levels of some of these molecules such as E-selectin, P-selectin, ICAM-1 and VCAM-1 have been explored in essential hypertension (16-26). The relationship between Creactive protein (CRP) and hypertension has also been studied $(27,28)$ wherein prevalence of hypertension was demonstrated to be high in subjects with second, third and fourth quartile of high sensitivity (hs) CRP as compared to subjects in the first quartile. In India Hypertension has emerged as a major public health problem (29). The prevalence of hypertension (systolic blood pressure [SBP]/ diastolic blood pressure [DBP] $\geq 160 /$ $\geq 95 \mathrm{mmHg}$ ) in urban population has increased from $2-4 \%$ to $10-15 \%$ and in rural population from $1-2 \%$ to $4-8 \%$ from mid1950 s to at the end of 20th century (30). To evaluate the significance of above inflammatory markers in hypertension, soluble levels of CAMs which are index of their increased expression were analysed in subjects diagnosed with high blood pressure at the time of the recruitment of the study and confirmed with hypertension with no secondary cause and their levels were again evaluated at 3 months to know the influence of antihypertensive treatment.

\section{MATERIALS AND METHODS}

Subjects detected with elevated BP (SBP/DBP > 135/85mmHg as per National Cholesterol Education [NCEP] ATP III Guideline) (31) at the time of the recruitment in the study and ruled out for any secondary causes were selected under hypertension group. They were all non-diabetic with fasting blood sugar below $110 \mathrm{mg} / \mathrm{dl}$. They were then prescribed antihypertensive medications such as Angiotensin converting enzyme (ACE) inhibitors, Angiotensin Il type 1 receptor (AT1R) blockers, Beta-blockers, Calcium channel blockers and Diuretics. The controls were healthy individuals with SBP/DBP $\leq 135 / 85 \mathrm{~mm} \mathrm{Hg}$ or less, with no other risk factors for CVD or clinical symptoms of any other organic disease.

Blood sample was collected after over night twelve hour fast. Those subjects with fasting glucose levels $>110 \mathrm{mg} / \mathrm{dl}$, serum transaminases, Blood Urea Nitrogen (BUN), and Creatinine levels beyond normal range or abnormal ECGs were excluded from the Control group. As per the selection criteria in each group, subjects were recruited with their informed consent. Information regarding their demographic status, clinical history, family history and medications were noted down in detail. The ethical committee of Sir H. N. Hospital and Research Centre approved the study protocol.

Estimation of Soluble levels of CAMs: An aliquot of serum was stored at $-80^{\circ} \mathrm{C}$ for estimation of $\mathrm{SE}$-selectin, sP-selectin, sICAM-1, sVCAM-1 and SPECAM-1 levels by commercially available enzyme-linked immunosorbent assay (ELISA) kits with monoclonal antibodies against each, according to the manufacturer's instructions. For determination of sICAM-1, sVCAM-1, sE-selectin, and sP-selectin, ELISA kits from R \& $D$ Systems were used. The minimum detectable levels of sICAM-1, sVCAM-1, sE-selectin, and sP-selectin were 0.35 , $1.26,0.1$, and $0.5 \mathrm{ng} / \mathrm{ml}$ respectively. The intra assay coefficient of variations of SICAM-1, SVCAM-1, sE-selectin, and SPselectin, were $4.8 \%, 3.5 \%, 5.1 \%$ and $6.5 \%$, respectively and inter assay coefficient of variations were $10.1 \%, 7.7 \%, 7.4 \%$, and $7.1 \%$ respectively. SPECAM- 1 was analysed using ELISA kit from Bender MedSystem wherein minimum detectable level was $0.06 \mathrm{ng} / \mathrm{ml}$, intra assay coefficient of variation was $2.5 \%$ and inter assay coefficient of variation was $7.4 \%$. Serum hs CRP was analysed using enzyme immunoassay test kit from DSL (Webster, TX) with minimum detectable level of $1.6 \mathrm{ng} /$ $\mathrm{ml}$. The intra and inter assay coefficient of variations of hsCRP assay were $4.8 \%$ and $6.1 \%$ respectively.

Statistical analysis: Results are expressed as frequency and percentages, mean \pm SD for parametric variables and median with inter quartile ranges for non-parametric variables. Significance of difference in the distribution of frequency was measured by chi square statistics. For parametric variables analysis of significance of difference of means between two groups was performed by student's unpaired t-test and of same group between two collection points by paired t-test. For nonparametric variables analysis of significance of difference of medians between two groups was carried out by Mann Whitney- $U$ test and of same group between two collection 
points by Wilcoxon signed-rank test. Correlations were evaluated by Spearman's rank correlation test. P-value $<0.05$ was considered statistically significant. Analyses were performed using statistical software SPSS (version 15.0, Chicago, IL).

\section{RESULTS}

Demographic data of control and hypertension groups is as demonstrated in Table 1. The two groups were matched for age and BMI while SBP and DBP were significantly elevated in hypertension group as compared to controls.

Table 1: Demographic data of Control and Hypertension groups

\begin{tabular}{|c|c|c|c|}
\hline & Control & Hypertension & $P$ value \\
\hline No $(M / F)$ & $57(27 / 30)$ & $57(33 / 24)$ & \\
\hline Age (Years) & $47.6 \pm 9.69$ & $48.9 \pm 10.4$ & 0.492 \\
\hline Age $<40$ lage $\geq 40$ Years & $11 / 46$ & $09 / 48$ & 0.622 \\
\hline Pre/Post-menopausal women & $10 / 20$ & $10 / 14$ & 0.528 \\
\hline Height (Meters) & $1.63 \pm 0.10$ & $1.61 \pm 0.09$ & 0.391 \\
\hline Weight (Kg) & $67.5 \pm 14.3$ & $67.6 \pm 12.7$ & 0.097 \\
\hline BMI (Kg/meter $\left.{ }^{2}\right)$ & $25.1 \pm 4.43$ & $25.7 \pm 3.93$ & 0.442 \\
\hline Waist(Cms) & $86.5 \pm 11$ & $85.9 \pm 12.8$ & 0.795 \\
\hline Hip (Cms) & $97.8 \pm 11.4$ & $97.1 \pm 13.1$ & 0.767 \\
\hline Waist to hip Ratio & $0.88 \pm 0.071$ & $0.88 \pm 0.07$ & 0.767 \\
\hline $\mathrm{SBP}(\mathrm{mmHg})$ & $115.6 \pm 11.1$ & $156.3 \pm 17.1$ & 0.001 \\
\hline DBP (mm Hg) & $78.7 \pm 6.88$ & $97.9 \pm 15.1$ & 0.001 \\
\hline Total Cholesterol (mmol/L) & $5.65 \pm 3.92$ & $5.44 \pm 1.052$ & 0.693 \\
\hline HDL-Cholesterol (mmol/L) & $1.21 \pm 0.234$ & $1.25 \pm 0.249$ & 0.395 \\
\hline Total cholesterol/HDL-C & $4.7 \pm 0.23$ & $4.47 \pm 0.31$ & 0.733 \\
\hline Triglyceride $(\mathrm{mmol} / \mathrm{L})$ & $1.33 \pm 0.74$ & $1.48 \pm 0.86$ & 0.331 \\
\hline LDL cholesterol (mmol/L) & $3.61 \pm 2.32$ & $3.6 \pm 1.1$ & 0.999 \\
\hline WBC count $/ \mu \mathrm{l}$ & $6779 \pm 1518$ & $7447 \pm 1588$ & 0.005 \\
\hline Smoking & - & $01(1.7 \%)$ & \\
\hline Consumption of Alcohol & - & $7(12.3 \%)$ & \\
\hline Family History & $24(42.1 \%)$ & $41(69.5 \%)$ & 0.0013 \\
\hline Hyperlipidemia & $25(43.85 \%)$ & $39(68.4 \%)$ & 0.014 \\
\hline
\end{tabular}

Analysis of soluble levels of CAMs between control and Hypertension group: Table 2 depicts median of soluble levels of CAMs of control and hypertension group. As compared to controls there was significant rise observed in sE-selectin of $49.2 \%(p=0.001)$, sP-selectin of $54.3 \%(p=0.001)$, and sICAM1 of $18.9 \%(p=0.012)$ in hypertensive subjects. With respect to sVCAM-1, SPECAM-1 and hsCRP the differences in the medians between control and hypertension group were
Table 2: Soluble levels of cell adhesion molecules

\begin{tabular}{lccc}
\hline CAMs & $\begin{array}{c}\text { Control } \\
(\mathrm{n}=57)\end{array}$ & $\begin{array}{c}\text { Hypertension } \\
(\mathrm{n}=57)\end{array}$ & $\mathrm{P}$ value \\
\hline sE-selectin & 19.7 & 29.4 & 0.001 \\
(ng/ml) & $(12.9 / 31.7)$ & $\begin{array}{c}(20.2 / 41.3) \\
(49.2 \% \uparrow)\end{array}$ & \\
& & 169.75 & 0.001 \\
sP-selectin & 110 & $(134 / 201.5)$ & \\
(ng/ml) & $(80 / 150)$ & $(54.3 \% \uparrow)$ & \\
& & 314.6 & 0.012 \\
sICAM-1 & 264.7 & $(231 / 365)$ & \\
(ng/ml) & $(233 / 305)$ & $(18.9 \% \uparrow)$ & \\
& & 553 & 0.524 \\
sVCAM-1 & 497 & $(358 / 732)$ & \\
(ng/ml) & $(407 / 647)$ & $(11.26 \% \uparrow)$ & \\
& & 62.3 & 0.505 \\
sPECAM-1 & 51.3 & $(44.2 / 75.6)$ & \\
(ng/ml) & $(43.6 / 76)$ & $(21.4 \% \uparrow)$ & \\
& & 0.83 & 0.902 \\
hsCRP & 0.92 & $(0.29 / 1.64)$ & \\
(mg/L) & $(0.27 / 2.23)$ & $(9.78 \% \downarrow)$ & \\
& & & \\
\hline
\end{tabular}

statistically not significant. The analysis of CAMs according to gender, age groups, BMI groups, menopausal status, and family history with respective controls is depicted in Table 3 , $4,5,6$, and 7 respectively.

Correlation Data: Table 8 depicts correlation data. Within control group among all CAMs only SPECAM-1 demonstrated significant correlation with hsCRP. Within hypertension group significant negative correlation was observed of SP-selectin and SPECAM-1 with age.

Effect of antihypertensive treatment on soluble levels of cell adhesion molecules: Thirty seven out of 57 subjects detected with elevated blood pressure at the time of recruitment in the study and then started with antihypertensive treatment were followed up at three months. Eight of them were each on combination of calcium channel blocker plus beta blocker and on AT1R blocker while seven each were on calcium channel blocker, beta blocker and ACE inhibitors. Therefore analysis of soluble levels of CAMs was carried out on combined data of all the patients on different antihypertensives. Demographic data of these subjects is depicted in Table 9. There was significant decrease in both SBP and DBP from basal level to follow-up at 3 months. Figure 1 (sE-selectin and sP-selecitn), Figure 2 (sICAM-1 and sVCAM-1) and Figure 3 (sPECAM-1 and hsCRP) demonstrate soluble levels of CAMs before starting the medication and at follow up of 3 months. Among CAMs there was significant fall only in sP-selectin $(20.5 \%, p=0.006)$ (Figure 1$)$ and non- 

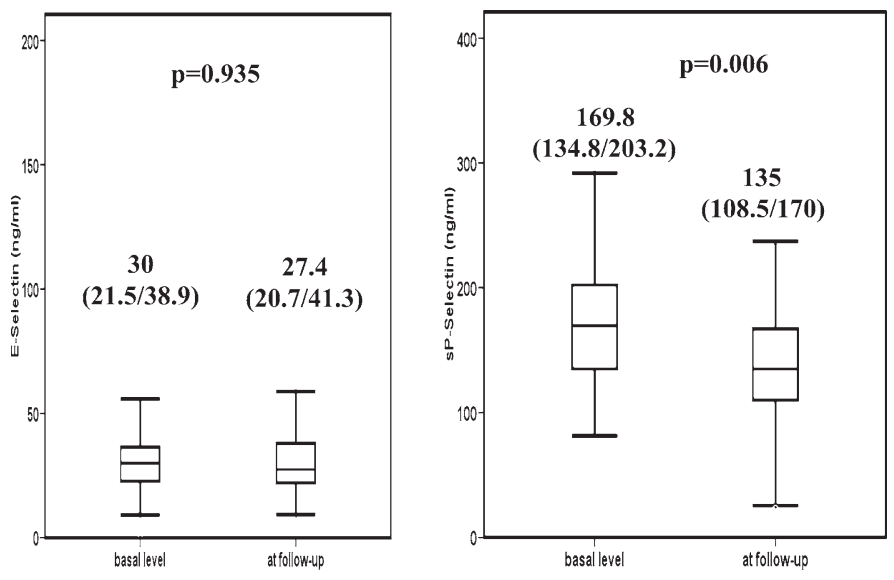

Fig 1: Soluble levels of E-selectin and P-selectin on follow-up of antihypertensive treatment
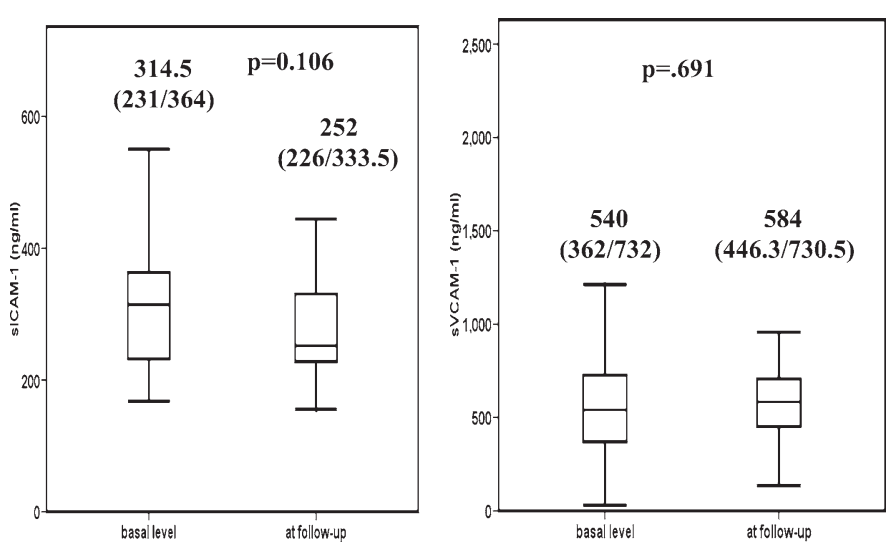

Fig 2: Soluble levels of ICAM-1 and VCAM-1 on follow-up of antihypertensive treatment
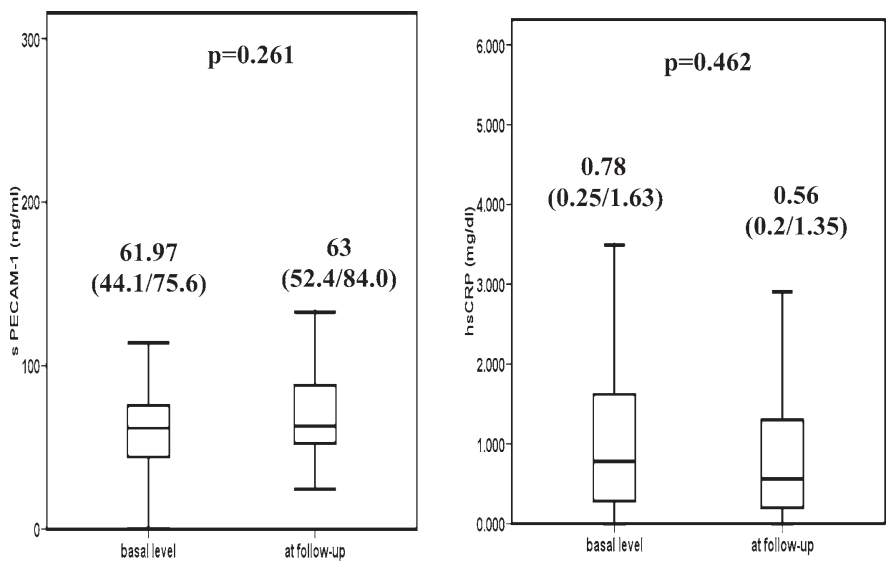

Fig 3: Soluble levels of PECAM-1 and hsCRP on follow-up of antihypertensive treatment significant fall sICAM-1 of $19.9 \%$ (Figure 2) while there was no significant change in any other soluble levels of CAMs. Follow up data of CAMs demonstrated strong correlation of sVCAM-1 with DBP $(r=0.449, p=0.047)$ and $s P$-selectin with $\operatorname{SBP}(r=0.749, p=0.005)$.

\section{DISCUSSION}

In the present study the status of soluble levels of CAMs that may aggravate the risk of atherosclerosis and thrombosis was determined in freshly diagnosed hypertensives.

We observed significant increased levels of sE-selectin, sPselectin and sICAM-1 as well as increasing trend of sVCAM1 in newly diagnosed hypertensives not yet treated with antihypertensives as compared to controls. Similar to our findings literature reports elevated levels of sE-selectin (1618), with exceptions by DeSouza et al (19) and Ferri et al (20); s-P-selectin (21-24), sICAM-1 (11, 17, 19, 25, 26) and sVCAM-1 (17-19) in hypertension. In the present study, as compared to controls increasing trend of SPECAM-1 in hypertension group was also observed.

E-selectin is a maker of endothelial activation. It demonstrated strong correlation with DBP within hypertension group. Blann et al (16) and Ferri et al (20) have reported similar findings. In the present study within both controls as well as hypertension group there was no significant difference in sE-selectin levels between subjects of BMI groups of $18-25 \mathrm{~kg} / \mathrm{m}^{2}$ and $>25-32$ $\mathrm{kg} / \mathrm{m}^{2}$. However median value of $\mathrm{sE}$-selectin of obese subjects of BMl group $>32 \mathrm{~kg} / \mathrm{m}^{2}$ as compared to $18-25 \mathrm{~kg} / \mathrm{m}^{2}$ and $>25-$ $32 \mathrm{~kg} / \mathrm{m}^{2} \mathrm{BMI}$ groups was elevated in control group by $94.5 \%$ and $63.0 \%$ (NS) and in hypertension group by $89.2 \%$ and $76 \%$ (NS) respectively. Ferri et al (32) have analysed the data of hypertension against control with obesity as additional risk factor and have reported that obesity causes elevation of sEselectin only. In their study plasma E-selectin correlated with BMI. However our data suggests that obesity in addition to blood pressure increases sE-selectin. In the present study sE-selectin was elevated by two fold in pre-menopausal hypertensive women as compared to healthy pre-menopausal women. Similar finding has been reported by Miller et al (33). However Lamon-fava et al (34) have reported that oestrogens can decrease the expression of CAMs. Increasing blood pressure in pre-menopausal women observed in our study and as suggested by Miller et al (33) may abolish the protective effect of oestrogen concentrations. Significant rise in sEselectin in pre-menopausal freshly diagnosed hypertensive women demonstrates susceptibility of these women towards atherosclerosis in spite of pre-menopausal status protection. 
Table 3: Soluble levels of cell adhesion molecules with respect to gender

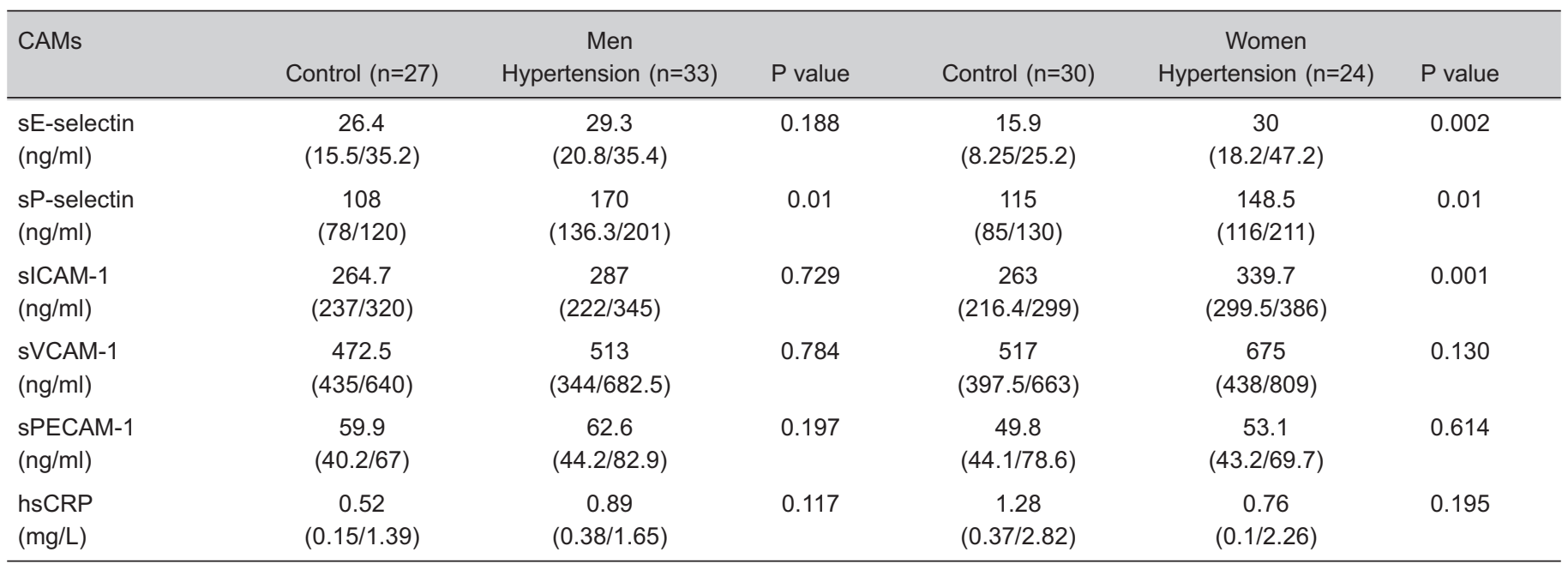

Elevated sP-slelectin is a marker of platelet activation and thus its increasing levels may impart thrombogenic status on these hypertensive subjects. In the present study healthy but obese individuals (BMI group $>32 \mathrm{Kg} / \mathrm{m}^{2}$ ) only demonstrated marginal but significant rise in sP-selectin of $18.2 \%(p=0.026)$ and $20.37 \%(p=0.042)$ as compared to BMl groups of $18-25 \mathrm{~kg} /$ $\mathrm{m}^{2}$ and $>25-32 \mathrm{~kg} / \mathrm{m}^{2}$ respectively. It also demonstrated strong positive correlation with total cholesterol. Similar to this finding Kvasnicka et al (35) have reported elevated levels of SPSelectin in overweight hyperlipidemics without clinical evidence of cardiovascular disease, diabetes or hypertension. Within hypertensive group SP-selectin demonstrated increasing trend with respect to $\mathrm{BMI}$ as well. Hypertensives with $\mathrm{BMI}>32 \mathrm{~kg} /$ $\mathrm{m}^{2}$ demonstrated remarkable rise in sP-selectin of $84.4 \%$ $(p=0.047)$ and $42.7 \%(\mathrm{NS})$ as compared to BMl groups 18 $25 \mathrm{~kg} / \mathrm{m}^{2}$ and $>25-32 \mathrm{~kg} / \mathrm{m}^{2}$ respectively. Among CAMs hypertensive men demonstrated prominent rise only in SP- selectin as compared to control men. Within hypertension group significant negative correlation was observed of SPselectin with age. Supporting the above data, hypertensives of age group $<40$ years demonstrated although non significant but increase in sP-selectin of $37.24 \%$ as compared to hypertensives of age group $\geq 40$ years.

ICAM-1 is constitutively expressed at low levels and is also influenced by cytokines. In the present study there was marginal but significant association of SICAM-1 with hypertension. sVCAM-1 also demonstrated non-significant trend towards hypertensives. Pre-menopausal hypertensive women demonstrated notable increase of sICAM-1 while postmenopausal hypertensive women demonstrated although nonsignificant similar rise in SVCAM-1 as compared to respective healthy women.

Table 4: Soluble levels of cell adhesion molecules with respect to age groups

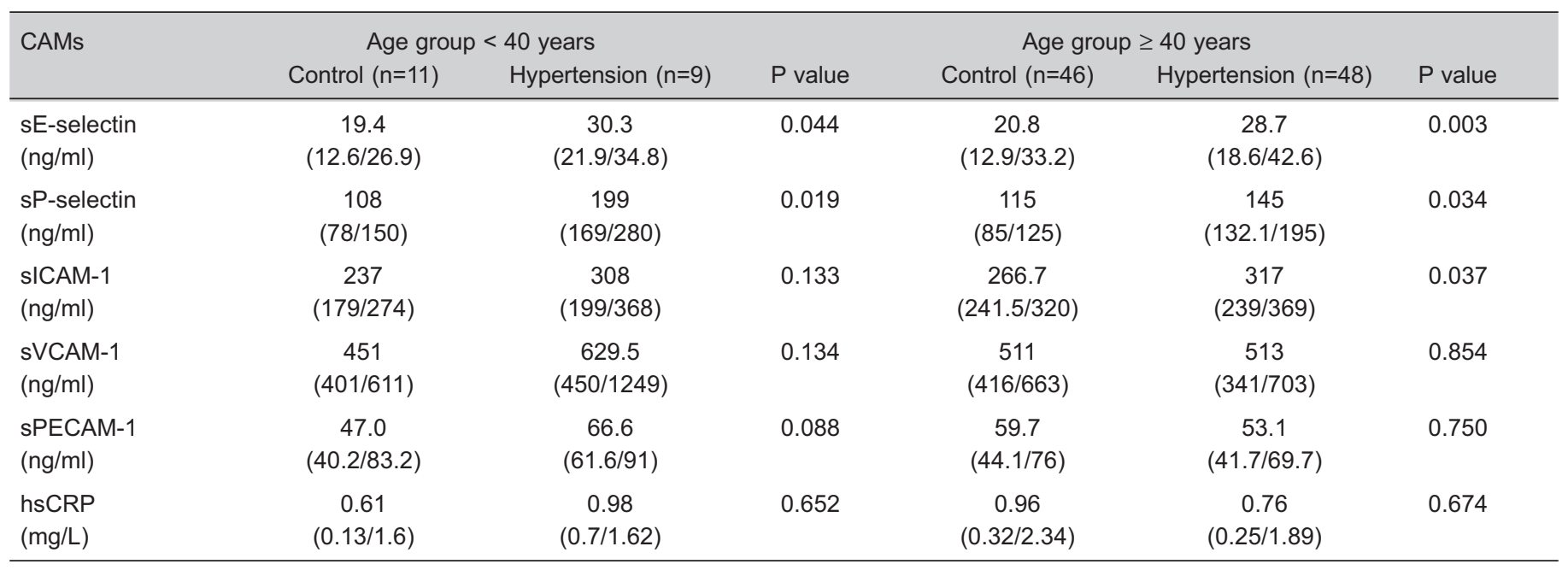


Table 5: Soluble levels of cell adhesion molecules with respect to BMI

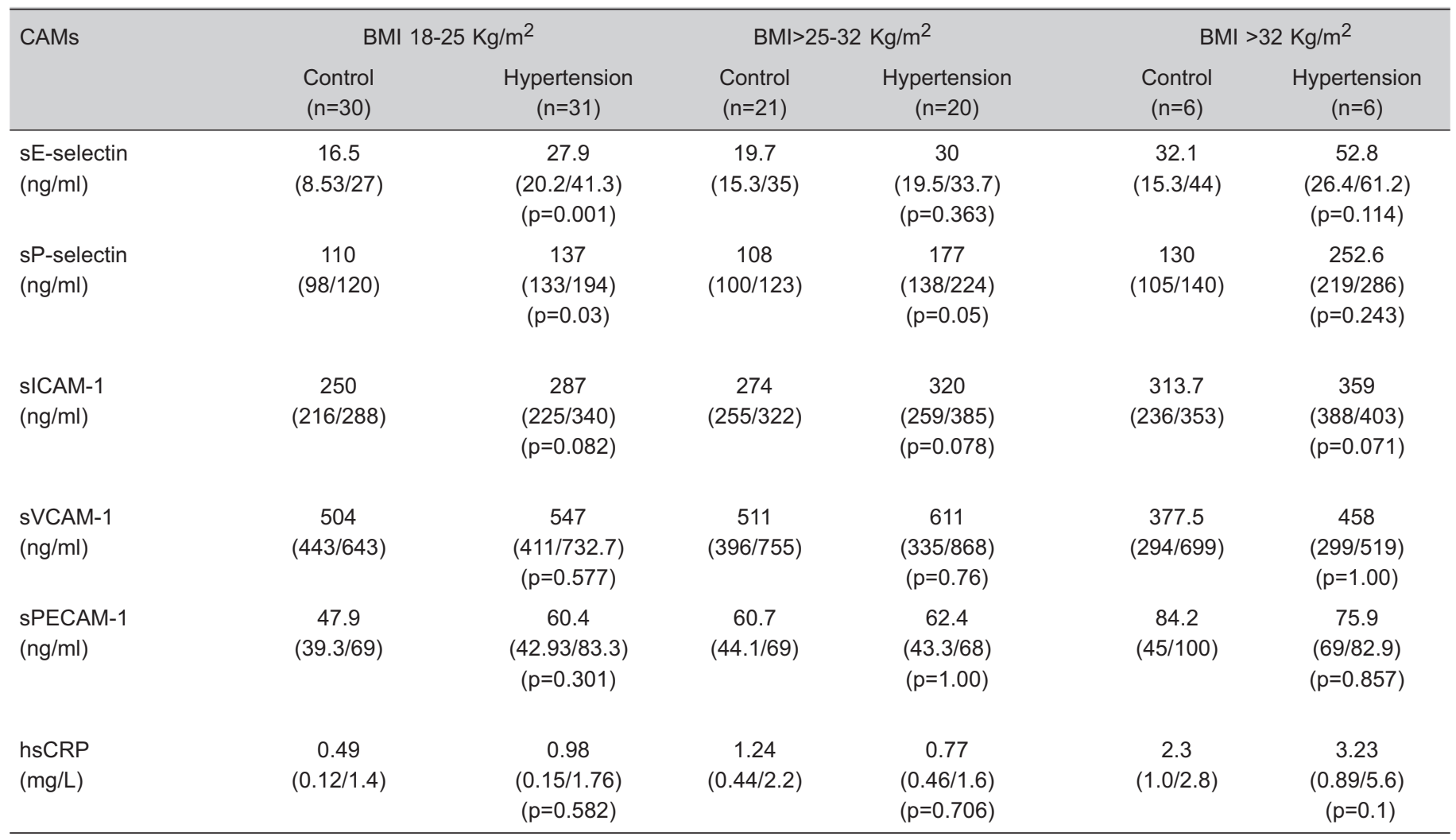

Another molecule that was high-lighted in the present study was SPECAM-1. It is with wide variety of function in platelet activation, inflammation, cell survival and immune response and has role in atherosclerotic plaque as well as thrombus formation. Within control group it demonstrated significant correlation with hsCRP. Elevated SPECAM-1 has been reported in pregnancy induced hypertension by Zeister et al (36) and in women with preclampsia by Krauss et al $(37,38)$.
Ours is the first study to report strong negative correlation of sPECAM-1 with age in hypertensive subjects with no secondary cause with corresponding rise in hypertensives of age group $<40$ years $(25.4 \%[p=0.037])$ as compared to age group $\geq 40$ years and in pre-menopausal hypertensive women $(56.1 \%[p=0.02])$ as compared to post-menopausal hypertensive women.

Table 6: Soluble levels of cell adhesion molecules with respect to menopausal status

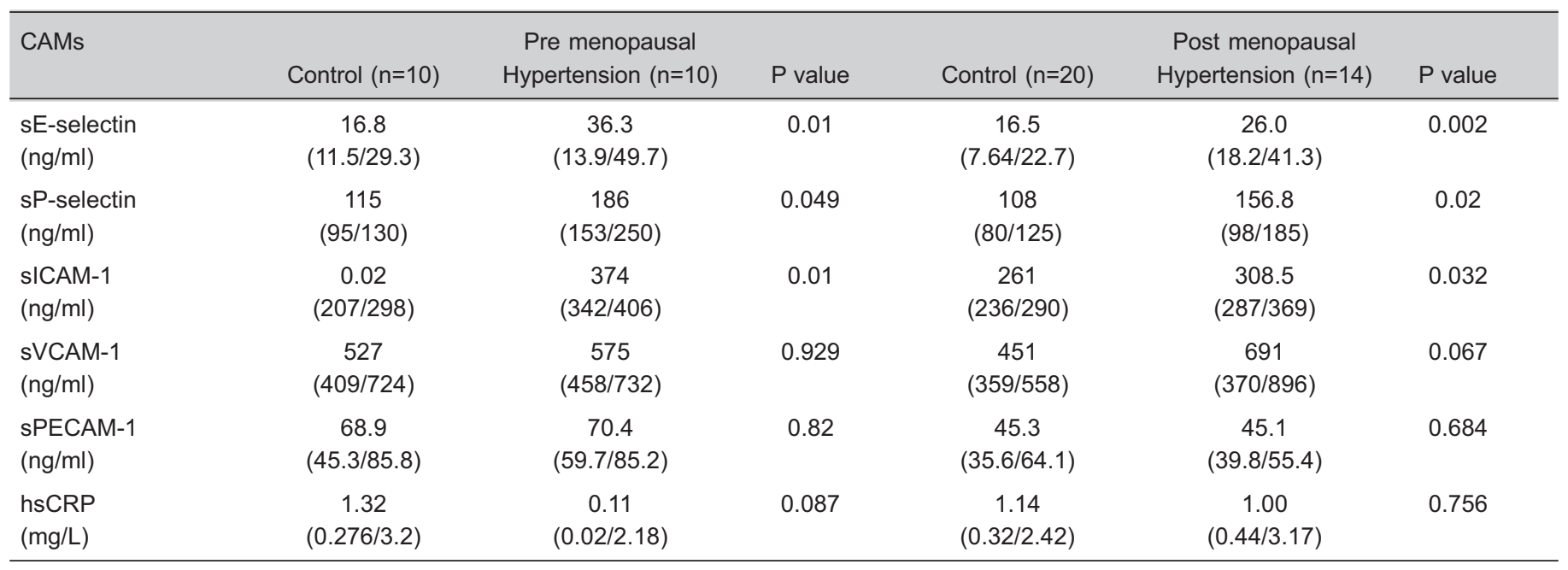


Table 7: Soluble levels of cell adhesion molecules with respect to family history of cardiovascular disease

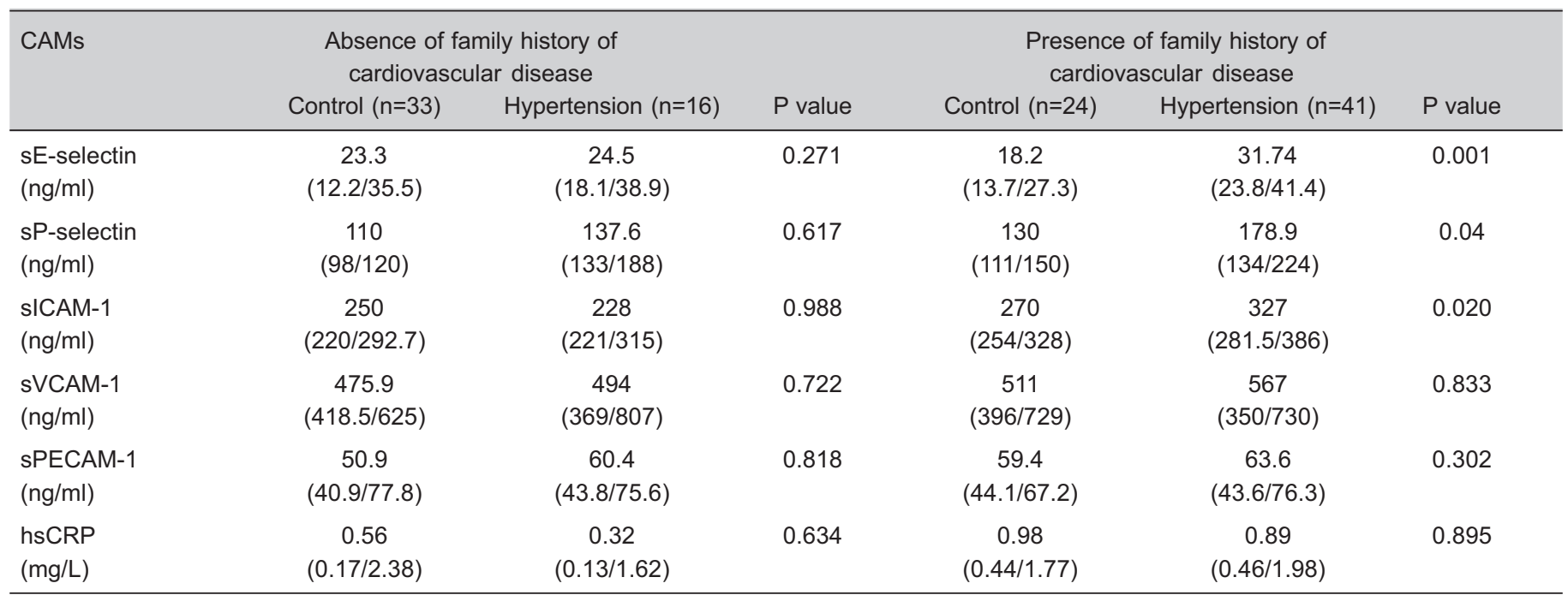

Table 8: Bivariate correlation within control and hypertension group

\begin{tabular}{|c|c|c|c|}
\hline & Risk factors & $r_{s}$ & $P$ value \\
\hline \multicolumn{4}{|c|}{ sCAMs in Controls } \\
\hline \multirow[t]{2}{*}{ sE-selectin } & Weight & 0.319 & 0.016 \\
\hline & Hip & 0.291 & 0.030 \\
\hline sP-selectin & Total Cholesterol & 0.277 & 0.037 \\
\hline \multirow[t]{9}{*}{ sICAM-1 } & BMI & 0.329 & 0.013 \\
\hline & Weight & 0.303 & 0.022 \\
\hline & Hip & 0.345 & 0.009 \\
\hline & SBP & 0.308 & 0.020 \\
\hline & DBP & 0.291 & 0.028 \\
\hline & Total cholesterol & 0.434 & 0.001 \\
\hline & Total Cholesterol/HDLC & 0.265 & 0.046 \\
\hline & Triglyceride & 0.282 & 0.033 \\
\hline & LDL-cholesterol & 0.366 & 0.005 \\
\hline \multirow[t]{3}{*}{ hsCRP } & BMI & 0.333 & 0.012 \\
\hline & Waist & 0.398 & 0.003 \\
\hline & sPECAM-1 & 0.469 & 0.001 \\
\hline \multicolumn{4}{|c|}{ sCAMs in Hypertension } \\
\hline sE-selectin & DBP & 0.271 & 0.046 \\
\hline \multirow[t]{2}{*}{ sP-selectin } & Age & -0.345 & 0.027 \\
\hline & Weight & 0.338 & 0.031 \\
\hline sICAM-1 & Triglyceride & 0.345 & 0.027 \\
\hline sPECAM-1 & Age & -0.446 & 0.003 \\
\hline hsCRP & Hip & 0.390 & 0.033 \\
\hline
\end{tabular}

$r_{\mathrm{s}}=$ Spearman's rank correlation coefficient
Several studies have been documented wherein protective effect of antihypertensives against vascular damage has been analysed. The studies have been carried out using ACE inhibitors $(39,40)$, AT1R blockers $(39,41-43)$, beta blockers (44) and calcium channel blockers (45-47). In the present study we could follow-up 37 of 57 hypertensive subjects after they had started with antihypertensive treatment. These patients were prescribed any one particular antihypertensive drugs discussed above. As there were only eight patients each on combination of calcium channel blocker plus beta blocker and on AT1R blockers and seven each on calcium channel blocker, beta blocker and ACE inhibitors, their data was combined. On follow-up there was significant fall only in sP-selectin and nonsignificant fall in sICAM-1 levels showing beneficial effect in addition to decrease in blood pressure while there was no significant change in SVCAM-1, SPECAM-1 or sE-selectin levels. Thus, SPECAM-1 may add risk of atherothrombosis to hypertensives even after control of blood pressure. Decrease in SP-selectin has been reported by ACE inhibitors (39), AT1R blockers (42), beta blocker (44) and calcium channel blocker (45-47).

In the present study median of hsCRP did not increase significantly in the hypertensives as compared to controls as documented in the literature $(27,28)$. Healthy Asian Indians are reported to have both greater insulin resistance and higher hs-CRP levels than do European Whites (48). In another study from United States, similar relationship was reported between Asians Indians and Caucasians (49) suggesting that many Asian Indians have an underlying proinflammatory state. Some of the reasons for elevated basal hsCRP levels; a marker of low-grade inflammation, have been highlighted in many studies 
Table 9: Follow up at 3 months of hypertensive subjects on treatment

\begin{tabular}{|c|c|c|c|}
\hline & & rtension & \\
\hline & At Basal level & on follow up & $P$ value \\
\hline No $(M / F)$ & $37(27 / 10)$ & & \\
\hline Age (Years) & $51.91 \pm 9.63$ & & \\
\hline $\mathrm{Ht}$ (Meters) & $1.62 \pm 0.10$ & $1.59 \pm 0.09$ & 0.375 \\
\hline Weight (Kg) & $68.21 \pm 10.52$ & $67.26 \pm 9.64$ & 0.174 \\
\hline BMI (Kg/meters $\left.{ }^{2}\right)$ & $26.53 \pm 4.14$ & $26.37 \pm 4.57$ & 0.581 \\
\hline Waist (Cms) & $89.53 \pm 10.59$ & $90.35 \pm 9.77$ & 0.376 \\
\hline Hip (Cms) & $101.3 \pm 10.05$ & $101.06 \pm 10.45$ & 0.912 \\
\hline Waist to hip Ratio & $0.88 \pm 0.073$ & $0.89 \pm 0.068$ & 0.525 \\
\hline $\mathrm{SBP}(\mathrm{mmHg})$ & $157.9 \pm 17.6$ & $106.1 \pm 14.65$ & 0.001 \\
\hline $\mathrm{DBP}(\mathrm{mmHg})$ & $126.5 \pm 21.51$ & $87.45 \pm 9.88$ & 0.001 \\
\hline $\begin{array}{l}\text { Total Cholesterol } \\
(\mathrm{mmol} / \mathrm{L})\end{array}$ & $5.64 \pm 36.2$ & $5.23 \pm 1.01$ & 0.111 \\
\hline HDL-C (mmol/L) & $1.31 \pm 0.262$ & $1.32 \pm 0.263$ & 0.842 \\
\hline $\begin{array}{l}\text { Total cholesterol/ } \\
\text { HDL-C }\end{array}$ & $4.3 \pm 0.84$ & $3.96 \pm 0.82$ & 0.117 \\
\hline Triglyceride $(\mathrm{mmol} / \mathrm{L})$ & $1.34 \pm 0.68$ & $1.38 \pm 0.68$ & 0.062 \\
\hline $\begin{array}{l}\text { LDL Cholesterol } \\
(\mathrm{mmol} / \mathrm{L})\end{array}$ & $3.52 \pm 0.99$ & $3.24 \pm 0.79$ & 0.778 \\
\hline WBC count $/ \mu l$ & $7495 \pm 1177$ & $7029 \pm 1443$ & 0.097 \\
\hline $\begin{array}{l}\text { Ca-channel plus } \\
\text { Beta blocker }\end{array}$ & 8 & & \\
\hline $\begin{array}{l}\text { Calcium channel } \\
\text { blocker }\end{array}$ & 7 & & \\
\hline Beta blocker & 7 & & \\
\hline ACE inhibitor & 7 & & \\
\hline AT1R blocker & 8 & & \\
\hline
\end{tabular}

(50-51) and therefore larger population study with extensive analysis between plasma hsCRP and various parameters of demographic data, body composition, fat distribution and insulin sensitivity etc. will be required to determine its exact status in hypertension.

Overall small sample size is a major limitation of the study. Subsequently, although 37 of freshly diagnosed hypertensives who started on medications came for the follow-up study; there were only few subjects under each antihypertensive treatment. Therefore the effect of one particular drug on soluble levels of CAMs could not be studied. Follow up of longer duration is essential so as to analyse the beneficiary effect of these drugs in addition of maintaining normal blood pressure. Other aspects that could not be analysed in our study were the status of soluble levels of CAMs with respect to smoking habit and consumption of alcohol, as there was only one hypertensive subject with smoking habit and seven with occasional alcohol consumption.

Novel finding of our study is strong negative correlation of SPECAM-1 and sP-selectin with age in hypertension group. Clinical and laboratory evidence suggests that hypertension may confer a prothrombotic or hypercoaguable state with abnormalities of coagulation, platelets and the endotheliumin fulfillment of Virchow's triad for thrombogenesis (52). Our results suggest that these makers may be useful and specific for pressure-induced endothelial and platelet activation with crucial role in increased atherothrombotic tendency seen in hypertension.

\section{ACKNOWLEDGEMENT}

Authors would like to acknowledge the financial support given by Sir H. N. Medical Research Society for the present study.

\section{REFERENCES}

1. Singh RB, Bajaj S, Niaz MA, Rastogi SS, Moshiri M. Prevalence of type 2 diabetes mellitus and risk of hypertension and coronary artery disease in rural and urban population with low rates of obesity. Int J Cardiol 1998; 66: 65-72.

2. The National High Blood Pressure Education Program Working Group. Report on hypertension in diabetes. Hypertens 1994; 23: 145-58.

3. Ghaffar A, Reddy KS, Singhi M. Burden of noncommunicable diseases in South Asia. BMJ 2004; 328: 807-10.

4. Chobanian AV, Alexander RW. Exacerbation of atherosclerosis by hypertension. Potential mechanisms and clinical implications. Arch Intern Med 1996; 156: 1952-6.

5. Alexander RW. Hypertension and the Pathogenesis of Atherosclerosis Oxidative Stress and the Mediation ofArterial Inflammatory Response: A New Perspective. Hypertension 1995; 25: 155-61.

6. Ross R, Glomset J, Harker L: Response to injury and atherogenesis. Am J Pathol 1997; 86: 675-84.

7. Mulvihill N. T, Foley JB, Crean P, Walsh M. Prediction of cardiovascular risk using soluble cell adhesion molecules. Euro Heart J 2002; 23:1569-74.

8. Muller WA, WeigI SA, Deng X, Philips. PECAM-1 is required for transendothelial migration of leukocytes. J Exp Med 1993; 178: 449-60.

9. Luft FC, Mervaala E, Muller DN, Gross V, Schmidt F, Park JK, et al. State-of-the-art. Lecture: hypertension-induced endorgan damage: a new transgenic approach to an old problem. Hypertens 1999; 33: 212-8. 
10. Laursen JB, Rajagopalan S, Galis Z, Tarpey M, Freeman BA, Harrison DG. Role of superoxide in angiotensin II induced but not catecholamine-induced hypertension. Circulation 1997; 95: 588-93.

11. Cottone S, Mule G, Nardi E, Vadala A, Lorito MC, Guarneri $M$, et al. C-reactive protein and intercellular adhesion molecule-1 are stronger predictors of oxidant stress than blood pressure in established hypertension. J Hypertens 2007; 25: 423-8.

12. Griendling KK, Alexander RW. Cellular biology of blood vessels. In: The Heart Hurst's $8^{\text {th }}$ edn. Ed. Schlant RC, Alexander RW, McGraw-Hill Publication Co., New York, NY; 1994: pp31-45.

13. Sen CK, Packer L. Antioxidant and redox regulation of gene transcription. FASEB J 1996; 10: 709-20.

14. Davies PF, Barbee KA, Volin MV, Robotewskyj A, Chen J, Joseph L, et al. Spatial relationships linearly signalling events of flow-mediated endothelial mechanotransduction. Ann Rev Physiol 1997; 59: 527-49.

15. Buemi M, Allegra A, Aloisi C, Corica F, Alonci A, Ruello A, et al. Cold pressor test raises serum concentrations of ICAM1, VCAM-1, and E-selectin in normotensive and hypertensive patients. Hypertens 1997; 30: 845-7.

16. Blann AD, Tse W, Maxwell SJ, Waite MA. Increased levels of the soluble adhesion molecule E-selectin in essential hypertension. J Hypertens 1995; 13:1674-8.

17. Cottone S, Mule G, Amato F, Riccobene R, Vadala A, Lorito $\mathrm{MC}$, et al. Amplified biochemical activation of endothelial function in hypertension associated with moderate to severe renal failure. J Nephrol 2002; 15:643-8.

18. Palomo I, Marín P, Alarcon M, Gubelin G, Vinambre X, Mora $E$, et al. Patients with essential hypertension present higher levels of sE-selectin and SVCAM-1 than normotensive volunteers. Clin Exp Hypertens 2003; 8: 517-23.

19. DeSouza CA, Dengel DR, Macko RF, Cox K, Seals DR. Elevated levels of circulating cell adhesion molecules in uncomplicated essential hypertension. Am J Hypertens 1997; 10: $1335-41$.

20. Ferri C, Desideri G, Baldoncini R, Bellini C, Angelis C. Massocchi $C$, et al. Early activation of vascular endothelium in nonobese, nondiabetic essential hypertensive patients with multiple metabolic abnormalities. Diabetes 1998; 47: 660-7.

21. Lip GY, Blann AD, Zarifis J, Beevers M, Lip PL, Beevers DG. Soluble adhesion molecule P-selectin and endothelial dysfunction in essential hypertension: implications for atherogenesis? A preliminary report. J Hypertens 1994; 12 : 925-8.

22. Ridker PM, Buring JE, Rifai N. Soluble P-selectin and the risk of future cardiovascular events. Circulation 2001; 103 : 491-5.
23. Nadar SK, Blann AD, Kamath S, Beevers DG, Lip GY. Platelet indexes in relation to target organ damage in highrisk hypertensive patients: a substudy of the AngloScandinavian Cardiac Outcomes Trial (ASCOT). Int J Cardiol 2004: 94: 293-300.

24. Varughese GI, Patel JV, Tomson J, Blann AD, Hughes EA, Lip GY. Prognostic value of plasma soluble P-selectin and von Willebrand factor as indices of platelet activation and endothelial damage/dysfunction in high-risk patients with hypertension: a sub-study of the Anglo-Scandinavian Cardiac Outcomes Trial. J Intern Med 2007; 261: 384-91.

25. Madej A, Okopien B, Kowalski J, Haberka M, Herman ZS. Plasma concentrations of adhesion molecules and chemokines in patients with essential hypertension. Int J Cardiol 2005; 98: 39-44.

26. Hong S, Nelesen RA, Krohn PL, Mills PJ, Dimsdale JE. The association of social status and blood pressure with markers of vascular inflammation. Pharmacol Rep 2005; 57: 878-81.

27. Bautista LE, Lopez-Jaramillo P, Vera LM, Casas JP, Otero AP, Guaracao Al. Is C-reactive protein an independent risk factor for essential hypertension? J Hypertens 2001; 19 : 857-61.

28. Sung KC, Suh JY, Kim BS, Kang JH, Kim H, Lee MH, et al. High sensitivity C-reactive protein as an independent risk factor for essential hypertension. Am J Hypertens 2003; 16 : 429-33.

29. Yusuf S, Reddy KS, Ounpuu S, Anand S. Global burden of cardiovascular diseases. Part I: general considerations, the epidemiologic transition, risk factors, and impact of urbanisation. Circulation 2001; 104: 2746-53.

30. Gupta R, Sharma AK, Gupta VP, Bhatnagar S, Rastogi $S$, Deedwania PC. Increased variance in blood pressure distribution and changing hypertension prevalence in an urban Indian population. J Hum Hypertens 2003; 17, 535-40.

31. Expert panel on detection, evaluation and treatment of high blood cholesterol in adults: Executive summary of the third report of the National College of Education Program (ATPIII) Expert panel on detection, evaluation and treatment of high blood cholesterol in adults: (Adult Treatment Panel III). JAMA 2001; 285: 2486-97.

32. Ferri C, Desideri G, Valenti M, Bellini C, Pasin M, Sanucci A, et al. Early upregulation of endothelial adhesion molecules in obese hypertensive men. Hypertens 1999; 34: 568-73.

33. Miller MA, Kerry SM, Cook DG, Cappuccio FP. Cellular adhesion molecules and blood pressure: interaction with sex in a multi-ethnic population. J Hypertens 2004; 22: 705-11.

34. Lamon-fava S, Posfai B, Schaeger EJ. Effect of hormonal replacement therapy on C-reactive protein and cell-adhesion molecules on postmenopausal women. Am J Cardiol 2003; 91: $252-4$. 
35. Kvasnicka T, Kvasnicka J, Ceska R, Grauova B, Vrablik M. Increasing plasma levels of soluble cell adhesion molecules (sE-Selectin, sP-Selectin and sICAM-1) in overweight adults with combined hyperlipidemia. Sb Lek 2001; 102: 473-7.

36. Zeisler H, Livington JC, Schatten C, Tempfer C, Knofler M, Husslin P. Serum levels of adhesion molecules in women with pregnancy-induced hypertension. Wein Klin Wochenschr 2001; 113: 588-92.

37. Krauss T, Kuhn W, Lakoma C, Augustin HG. Circulating endothelial cell adhesion molecules as diagnostic markers for the early identification of pregnant women at risk for development of pre-eclampsia. Am J Obstet Gynecol 1997; 177: 443-9.

38. Krauss T, Osmers R, Beran J, Diedrich F, Fleckenstein G, Kuhn W. Soluble adhesion molecules in patients with preeclampsia. Zentralbl Gynakol 1998; 120: 279-83.

39. Li-Saw-Hee FL, Beevers DG, Lip GY. Effect of antihypertensive therapy using enalapril or losartan on haemostatic markers in essential hypertension: a pilot prospective randomized double-blind parallel group trial. Int J Cardiol 2001; 78: 241-6.

40. Hlubocka Z, Umnerova V, Heller S, Peleska J, Jindra A, Jachymova $M$, et al. Circulating intercellular cell adhesion molecule-1, endothelin-1 and von willebrand factor markers of endothelial dysfunction in uncomplicated essential hypertension: the effect of ACE inhibitors. J Hum Hypertens 2002; 16: 557-62.

41. Conen D, Everett BM, Glynn RJ, Ridker PM. Effect of valsartan compared with valsartan/hydrochlorothiazide on plasma levels of cellular adhesion molecules: the Val-MARC trial. Heart 2008; 94: e13.

42. Liu L, Zhao SP, Zhou HN, Li QZ, Li JX. Effect of fluvastatin and valsartan, alone and in combination, on postprandial vascular inflammation and fibrinolytic activity in patients with essential hypertension. J Cardiovasc Pharmacol 2007; 50: 50-5.

43. Ridker PM, Danielson E, Rifai N, Glynn RJ; Val-MARC Investigators. Valsartan, blood pressure reduction, and Creactive protein: primary report of the Val-MARC trial. Hypertens 2006; 48: 73-9.
44. Celik T, Yuksel UC, Iyisoy A, Kursaklioglu H, Ozcan O, Kilic $S$, et al. Effects of nebivolol on platelet activation in hypertensive patients: a comparative study with metoprolol. Int J Cardiol 2007; 116: 206-11.

45. Nomura S, Kanazawa S, Fukuhara S. Effects of efonidipine on platelet and monocyte activation markers in hypertensive patients with and without type 2 diabetes mellitus. J Hum Hypertens 2002; 16: 539-47.

46. Sanada H, Midorikawa S, Yatabe J, Yatabe MS, Katoh T, Baba T, et al. Elevation of serum soluble E- and P-selectin in patients with hypertension is reversed by benidipine, a long-acting calcium channel blocker. Hypertens Res. 2005; 28: 871-8.

47. Nomura S, Shouzu A, Omoto S, Nishikawa M, Iwasaka T. Long-term treatment with nifedipine modulates procoagulant marker and $\mathrm{C}-\mathrm{C}$ chemokine in hypertensive patients with type 2 diabetes mellitus. Thromb Res 2005; 115: 277-85.

48. Chambers JC, Eda S, Bassett P, Karim Y, Thompson SG, Gallimore JR, et al. C-reactive protein, insulin resistance, central obesity, and coronary heart disease risk in Indian Asians from the United Kingdom compared with European whites. Circulation 2001; 104: 145-50.

49. Chandalia M, Cabo-Chan AV Jr, Devaraj S, Jialal I, Grundy $\mathrm{SM}$, Abate N. Elevated plasma high-sensitivity C-reactive protein concentrations in Asian Indians living in the United States. J Clin Endocrinol Metab 2003; 88: 3773-6.

50. Vikram NK, Misra A, Dwivedi M, Sharma R, Pandey RM, Luthra $\mathrm{K}$, et al. Correlations of $\mathrm{C}$-reactive protein levels with anthropometric profile, percentage of body fat and lipids in healthy adolescents and young adults in urban North India. Atherosclerosis 2003; 168: 305-13.

51. Deepa R, Velmurugan K, Arvind K, Sivaram P, Sientay C, Uday $S$, et al. Serum levels of interleukin 6, C-reactive protein, vascular cell adhesion molecule 1, and monocyte chemotactic protein 1 in relation to insulin resistance and glucose intolerance- - the Chennai Urban Rural Epidemiology Study (CURES). Metabolism 2006; 55: 1232-8.

52. Lip GYH. Hypertension and the prothrombotic state. J Hum Hypertens 2000; 14: 687-90. 